\title{
Tuberculosis colliquativa cutis of the cheek: an extremely uncommon manifestation of primary extrapulmonary tuberculosis
}

\author{
Monica Gupta, ${ }^{1}$ Manish Gupta, ${ }^{2}$ Rupinder Kaur ${ }^{3}$
}

${ }^{1}$ Department of Medicine, Government Medical College and Hospital, Chandigarh, India

2Department of ENT, Gian Sagar Medical College, Chandigarh, India

${ }^{3}$ Department of Pathology, Gian Sagar Medical College, Patiala, Punjab, India

\section{Correspondence to} Dr Monica Gupta, monicamanish2001@gmail. com

To cite: Gupta $\mathrm{M}$ Gupta M, Kaur R. BMJ Case Rep Published online: [please include Day Month Year] doi:10.1136/bcr-2013 009058

\section{DESCRIPTION}

Extrapulmonary tuberculosis (EPTB) can occur as an isolated entity or along with a pulmonary focus as in disseminated tuberculosis. Although increasingly diagnosed nowadays owing to immunodeficiency states, EPTB never fails to surprise the medical community by appearing at the rarest of the rare sites and its novel structure or appearance. The variable and myriad presentations of primary EPTB create an extremely challenging situation for the dealing physicians. However, whatever may be the presentation, it is highly gratifying to diagnose and treat this curable disease. Our case was a middle-aged, immunocompetent patient with primary tubercular granuloma of cheek.

A 39-year-old female patient presented in the outpatient department, with right-sided facial swelling. The swelling had been gradually increasing in size for the previous 4 months with occasional bouts of pain. There were no associated nasal, ocular or dental complaints. There was no history of cough, fever, decreased appetite or weight loss. On examination, $2.5 \times 2 \mathrm{~cm}$ firm swelling was palpable on the anterolateral wall of the right maxilla just over canine fossa, blunting the nasolabial fold. It appeared fixed to the underlying bone, but the overlying skin was mobile and smooth with no scars or sinuses. The swelling was slightly tender and did not cause any bulge in the gingivobuccal sulcus. The general physical state and the rest of the ear, nose and throat examinations were normal.

During the initial workup, fine needle aspiration cytology (FNAC) from the mass was performed; however, two FNAC reports were inconclusive and yielded only the necrotic material. Before contemplating an excision biopsy, contrast-enhanced CT of the nose and paranasal sinuses was performed, which revealed well-defined, lobulated, moderately enhancing soft tissue density mass of size $1.8 \times$ $1.2 \mathrm{~cm}$ in the right subcutaneous premaxillary space (figure 1). There was no evidence of maxillary bone erosion. Erythrocyte sedimentation rate was elevated, $50 \mathrm{~mm} / \mathrm{h}$ (Westergren method) and the tuberculin test yielded an induration of $18 \times$ $18 \mathrm{~mm}$. Rest of the biochemical, haematological investigations were normal. Chest radiograph was within the normal limits.

The patient was taken up for excision of mass via the sublabial route under local anaesthesia. The mass was found adherent to the underlying periosteum and was removed in toto. The histopathology revealed dense inflammatory infiltrate consisting of lymphocytes, plasma cells, macrophages, multiple Langhanstype giant cells and few epithelioid cell granulomas with area of caseation necrosis and fibrosis, suggestive of tuberculosis (figure 2). Ziehl-Neelsen (ZN) stain was positive for typical acid-fast Mycobacterium tuberculosis. Postoperatively, after histopathological and microbiological confirmation of tuberculosis, the patient was started on standard multidrug antitubercular therapy. The patient has completed her therapy of 6 months duration, and is disease-free at present.

EPTB constitutes about $10 \%$ of all the cases of tuberculosis (however, this percentage may vary from region to region, in the UK $~ 48 \%$ of tuberculosis cases are EPTB) and cutaneous tuberculosis makes up only a small proportion $(\sim 1 \%)$ of these cases. ${ }^{12}$ Cutaneous tuberculosis is further classified into primary inoculation tuberculosis, tuberculosis verrucosa cutis, lupus vulgaris, tuberculosis colliquativa cutis (subcutaneous tubercular granuloma, also called as scrofuloderma), tuberculosis cutis orificialis and tuberculosis cutis miliaris disseminata. ${ }^{3}$

Diagnosis of tuberculosis is difficult in such cases because of the absence of typical constitutional features. Microbiological tests such as direct microscopy and culture are usually negative in cutaneous tuberculosis because it is paucibacillary. ${ }^{2}$ Histopathological findings are characteristic but not pathognomonic and are shared by other granulomatous diseases including leprosy, sarcoidosis, leishmaniasis and subcutaneous fungal infections. ${ }^{4}$ To avoid diagnostic misinterpretation, CT scan, MRI or nuclear scans may be justified for anatomical localisation and differentiation.

Our finding of a firm soft tissue mass on the anterior aspect of the maxillary wall was representative of tuberculosis colliquativa cutis, which is a localised granulomatous tuberculous infection of

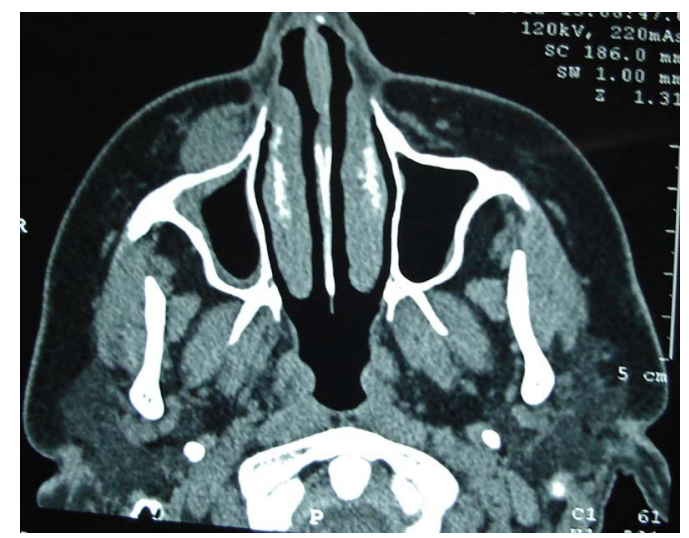

Figure 1 Contrast-enhanced CT of the axial section of the nose and paranasal sinuses showing the soft tissue mass over the anterolateral wall of the right maxilla. 


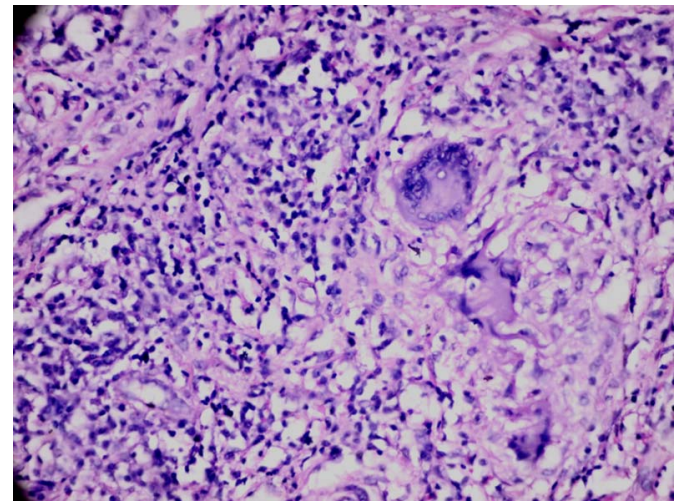

Figure 2 Langhans-type giant cell and epithelioid granuloma with chronic inflammatory infiltrate $(H \& E, \times 40)$.

the subcutaneous tissue. The differentials considered were the inflamed lymph node, sebaceous cyst, benign growth or the granulomatous lesion. Such a case of isolated primary EPTB is extremely rare, so much so that the precise origin of the tuberculous infection can just be speculated; possibly it could be parafacial tuberculous lymphadenitis, maxillary osteomyelitis or the infected periapical tissue of maxillary molar or canine.

Though the nested PCR (nPCR) is a good tool for detecting $M$ tuberculosis DNA, in one study the correlation between nPCR results and clinical outcome was less than optimal. ${ }^{4}$ Therefore in granulomatous diseases of the face, it is important to evaluate not only nPCR but also the overall clinicopathological picture so as to avoid diagnostic misinterpretation. The facility for nPCR is not available at our setup, thus was not performed in the present case.

\section{Learning points}

- Our case is a perfect example of the bizarre and atypical presentations of extrapulmonary tuberculosis (EPTB), reinstating the fact that mycobacteria can infect practically any organ of the human body.

- Diagnosis of EPTB requires high index of suspicion, even in the absence of constitutional symptoms and signs.

Contributors MOG is the physician and MAG is the ENT specialist who have seen and managed the case and have drafted the initial version of this manuscript. RK is the histopathologist who was involved in patient workup and management. All the authors have critically analysed the text, images and contributed significantly in shaping the final manuscript.

\section{Competing interests None.}

\section{Patient consent Obtained.}

Provenance and peer review Not commissioned; externally peer reviewed.

\section{REFERENCES}

1 Pedrazzoli D, Fulton N, Anderson L, et al. Tuberculosis in the UK: annual report on tuberculosis surveillance in the UK, 2012. London: Health Protection Agency, 2012.

2 Puri N. A clinical and histopathological profile of patients with cutaneous tuberculosis. Indian J Dermatol 2011;56:550-2.

3 Bugnit G, Sharma A, Sharma N. Subcutaneous granuloma of the cheek an unusual case report and review of literature. Indian J Otolaryngol Head Neck Surg 2006;58:205-6.

4 Ferrara G, Cannone M, Scalvenzi M, et al. Facial granulomatous disease: a study of four cases tested for the presence of Mycobacterium tuberculosis DNA using nested polymerase chain reaction. Am J Dermatopathol 2001;23:8-15.

Copyright 2013 BMJ Publishing Group. All rights reserved. For permission to reuse any of this content visit

http://group.bmj.com/group/rights-licensing/permissions.

BMJ Case Report Fellows may re-use this article for personal use and teaching without any further permission.

Become a Fellow of BMJ Case Reports today and you can:

- Submit as many cases as you like

- Enjoy fast sympathetic peer review and rapid publication of accepted articles

- Access all the published articles

- Re-use any of the published material for personal use and teaching without further permission

For information on Institutional Fellowships contact consortiasales@bmjgroup.com

Visit casereports.bmj.com for more articles like this and to become a Fellow 